\author{
Bunyakova Yu.Ya., Khetselius O.Yu., Florko T.A., \\ Glushkov A.V., Svinarenko A.A., Dubrovskaya Yu.V.
}

Odessa State Environmental University, Odessa

E-mail:florkota@gmail.com

\title{
A chaos-geometric approach to analysis, modelling and forecasting atmospheric pollutants dynamics for industrial regions
}

\begin{abstract}
We applied an advanced chaos-geometric approach to analysis, modeling, forecasting and processing the time series of the air pollutants $\left(\mathrm{NO}_{2}\right)$ concentrations in an atmosphere of the industrial cities (regions). The approach includes such advanced non-linear analysis and a chaos theory methods such as a multifractal approach, correlation integral algorithm, the Lyapunov's exponents and Kolmogorov entropy analysis, a power spectrum analysis, prediction models with neural networks blocks etc. The dynamical and topological invariants (including the Lyapunov's exponents spectrum, Kaplan-Yorke dimension, Kolmogorov entropy etc) for the air pollutants $\left(\mathrm{NO}_{2}\right)$ concentrations time series in an atmosphere of the industrial cities are computed. Our study has shown an existence of a deterministic chaos in the atmospheric pollutants fluctuations dynamics. It is presented an effective prediction model for description of the temporal evolutionary dynamics of the air pollutants concentration in atmosphere of the industrial city.
\end{abstract}

Key words: atmospheric pollutants dynamics, chaos-geometric approach.

Introduction. In this paper we present an advanced version of the chaosgeometric approach to analysis, processing and prediction of the scalar environmental measurement data, in particular, the time series of the atmospheric pollutants (dioxide of nitrogen) concentrations in an atmosphere of the industrial cities. The studies concerning non-linear behaviour in the time series of nature dynamical systems are sparse, and their outcomes are ambiguous (c.g., [1-8]). In Refs. [8-15] it has been presented an advanced chaos-geometric approach to analysis, modeling, forecasting and processing the time series of the air pollutants concentrations in an atmosphere of the industrial cities (regions). The approach includes such advanced non-linear analysis and a chaos theory methods such as a multifractal approach, correlation integral algorithm, the Lyapunov's exponents (LE) and Kolmogorov entropy (KE) analysis, a power spectrum analysis, prediction models with neural networks blocks etc. Here the results of computing the dynamical and topological invariants (including the Lyapunov's exponents spectrum, Kaplan-Yorke dimension, KE etc) for the air pollutants $\left(\mathrm{NO}_{2}\right)$ concentrations time series in an atmosphere of the industrial cities are listed. It is presented an advanced prediction model for description of the temporal evolutionary dynamics of the air pollutants.

The input data. Chaos-geometric approach. In our study, we have used the nitrogen dioxide concentration data, namely, the multi year hourly concentrations, observed at several sites of the Odessa (one year total of 20x6570 data points) and 


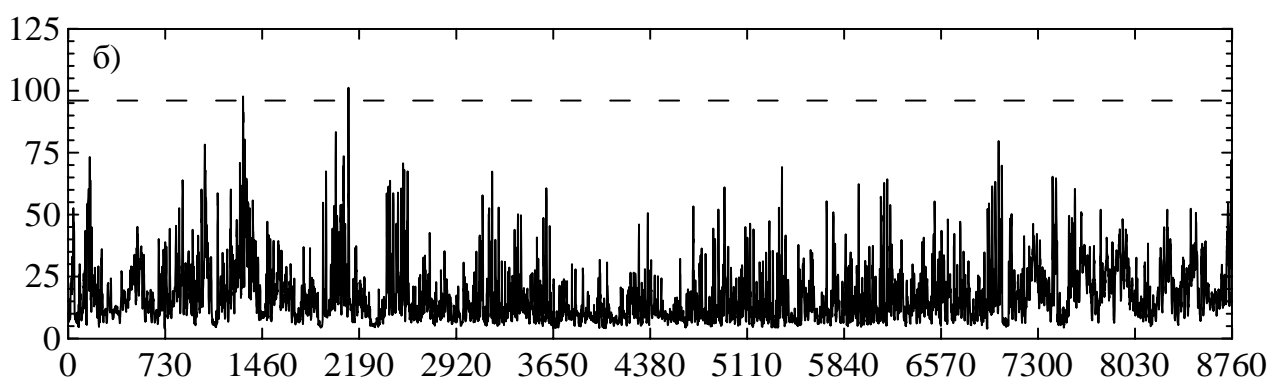

Fig. 1. The time series of concentrations $\left(\mu \mathrm{g} / \mathrm{m}^{3}\right)$ of the of the $\mathrm{NO}_{2}$

Gdansk (20x8760 data points) regions during 2001-2006 years. The typical time series of concentrations (in $\mu \mathrm{g} / \mathrm{m}^{3}$ ) of the $\mathrm{NO}_{2}$ are listed in fig. 1 [8].

Let us note that in the Gdansk region, the Agency of Regional Air Quality Monitoring (Armaag) provides presently the 24-h forecasts of air quality levels using the model called Calmet/Calpuff (see [1,8] and Refs. therein). In Refs. [8-12] it has been developed the computational code for studying chaotic features of the complex non-linear systems and in details described a procedure of testing of the chaos elements in the corresponding time series. In Table 1 we present the block-scheme of a chaos-geometric approach in application to air pollutants dynamics.

The detailed description of all blocks can be found in Refs. [5-12]. Below we are

Table 1.

A chaos-geometric approach to nonlinear analysis, modeling and prediction of atmospheric pollutants concentrations temporal and spatial dynamics

I. Preliminary study and assessment of the presence of chaos:

1. Test by Gottwald-Melbourne: $K \rightarrow 1$ - chaos;

2. Fourier decompositions, irregular nature of change - chaos;

3. Spectral analysis, Energy spectra statistics, the Wigner distribution, the spectrum of power, "Spectral rigidity"; $\Downarrow$

II. The geometry of the phase space. Fractal Geometry:

4. Computation time delay $\tau$ using autocorrelation function or mutual information;

5. Determining embedding dimension $d_{E}$ by the method of correlation dimension or algorithm of false nearest neighbouring points;

6. Calculation multi-fractal spectra. Wavelet analysis;

III. Prediction:

7. Computing global Lyapynov dimensions LE: $\lambda_{\alpha}$; Kaplan-York dimension $d_{L}, \mathrm{KE}$, average predictability measure $\operatorname{Pr}_{\max }$;

8. Determining the number of nearest neighbour points $\mathrm{NN}$ for the best prediction results;

9. Nonlinear prediction. Neural network algorithm, algorithm optimized trajectories. 
limited only by the key aspects. As usually, we study the concentration data $s(n)=s\left(t_{0}+n \Delta t\right)=s(n)$, where $t_{0}$ is a start time, $\Delta t$ is time step, and $n$ is number of the measurements. The first fundamental step of modelling is in reconstruction of the corresponding phase space using as well as possible information contained in $s(n)$. Using collection of time lags $\tau$ to create a vector in $d$ dimensions, $\mathrm{y}(n)=[s(n), s(n+\tau)$, $s(n+2 \tau), . ., s(n+(d-1) \tau)]$, the required coordinates are provided. The dimension $\mathrm{d}$ is the embedding dimension, $d_{E}$. The goal of the embedding dimension determination is to reconstruct a Euclidean space $R^{d}$ large enough so that the set of points $d_{A}$ can be unfolded without ambiguity. From the mathematical viewpoint, this procedure results in set of $d$-dimensional vectors $\mathrm{y}(n)$ replacing scalar measurements. There are a few approaches to the choice of proper time lag [5-9]. This point is important for the subsequent reconstruction of phase space. First approach is to compute the linear autocorrelation function $C_{L}(\delta)$ and to look for that time lag where $C_{L}(\delta)$ first passes through 0 . The alternative approach is based on using method of an average mutual information. The correlation integral analysis is one of the widely used techniques to investigate the signatures of chaos in a time series. This method is based on using the correlation integral, $C(r)$. As usually, if the corresponding time series is characterized by an attractor, then the correlation integral $C(r)$ is related to the radius $r$ as $d=\lim [\log C(r) / \log r]$, where $d$ is correlation exponent. The saturation value of this

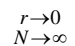

exponent is defined as the correlation dimension $\left(d_{2}\right)$ of the attractor (c.g. [5-12]). Another method for determining $d_{E}$ is given by the method of false nearest neighbours. As a rule, the simultaneous application of two methods provides more exact determination $d_{E}$. The further important step in studying the chaotic time series is determination of predictability, which can be estimated by the KE. The KE is proportional to a sum of the positive LE. The largest positive value of the LE determines some average prediction limit. Since the LE defined as asymptotic average rates, they are independent of the initial conditions. The estimate of the attractor dimension is provided by the conjecture $d_{L}$ and the LE are taken in descending order. The further development of the chaos-geometric approach was provided by development of new prediction models with standard interpolation methods (e.g., spline or polynomial) and neural networks blocks (all details are in refs. [11,13-16]).

Some results and conclusion. In Table 2 we present our advanced data on the parameters $\tau, K$, correlation dimension $\left(d_{2}\right)$, embedding dimension $\left(d_{E}\right)$, two $\operatorname{LE}\left(\lambda_{1}\right.$, $\lambda_{2}$ ), Kaplan-York dimension $\left(d_{L}\right)$, and average limit of predictability $\left(\operatorname{Pr}_{\max }\right.$, hours), KE $K_{\text {ent }}$ for time series of the $\mathrm{NO}_{2}$ at sites of the Odessa (2001) and Gdansk (2003) regions. If time lags determined by average mutual information are used, then algorithm of false nearest neighbours provides $d_{E}=6$ for all air pollutants. From the table 2 it can be noted that the Kaplan-Yorke dimensions, which are also the attractor dimensions, are smaller than the dimensions obtained by the algorithm of false nearest neighbours. It is very important to pay the attention on the presence of the two (from six) positive LE $\lambda_{i}$. This fact suggests that the system broadens in the line of two axes and converges along four axes that in the six-dimensional space $[8,9,13]$. 
Table 2.

The correlation dimension $\left(d_{2}\right)$, embedding dimension $\left(d_{E}\right)$, first two Lyapunov's exponents, $\mathrm{E}\left(\lambda_{1}, \lambda_{2}\right)$, Kaplan-Yorke dimension $\left(\mathrm{d}_{\mathrm{L}}\right)$, and average limit of predictability ( $\mathrm{Pr}_{\max }$, hours) for time series of $\mathrm{NO}_{2}$ at the Odessa and Gdansk sites

\begin{tabular}{|l|c|c|c|c|c|c|c|c|}
\hline$\tau$ & $d_{2}$ & $d_{E}$ & $\lambda_{1}$ & $\lambda_{2}$ & $d_{L}$ & $\operatorname{Pr}_{\max }$ & $K_{\text {ent }}$ & $K$ \\
\hline \multicolumn{7}{|c|}{ Site 2 Odessa region $(2001)$} \\
\hline 8 & 5.29 & 6 & 0.0191 & 0.0050 & 3.92 & 42 & 0.024 & 0.70 \\
\hline \multicolumn{7}{|c|}{ site 6 of Gdansk region $(2003)$} \\
\hline 9 & 5.31 & 6 & 0.0184 & 0.0061 & 4.11 & 40 & 0.025 & 0.68 \\
\hline
\end{tabular}

As example of using an approach to predict the time series, in Figure 2 we present the empirical (solid line 1) and forecasting (solid line 2 and dotted line 3) data for the $\mathrm{NO}_{2}$ concentration for the last one hundred points (Gdansk region, 2003) [8].

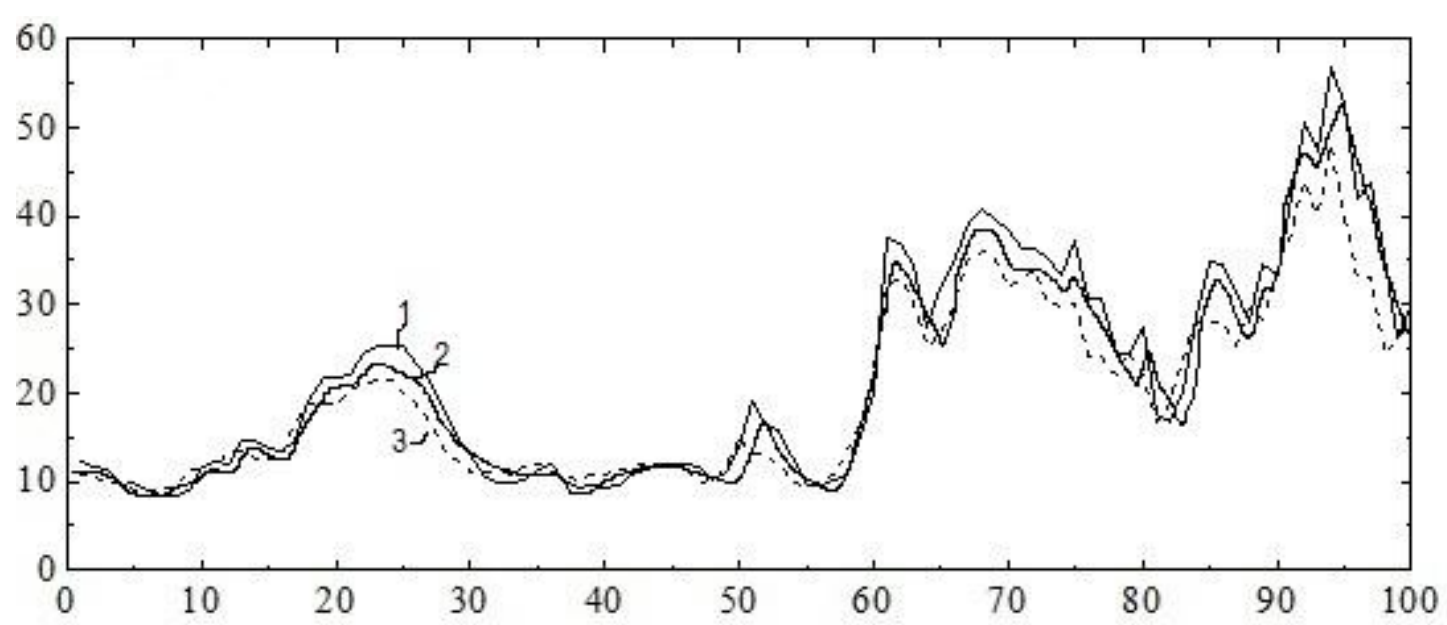

Fig. 2. The empirical (solid line 1) and forecasting (solid line 2 and dotted line 3) $\mathrm{NO}_{2}$ concentration lines for the last one hundred points (see text).

The theoretical predicted data (solid line 2) are obtained with using the Schreiber-type prediction algorithm with neural networks block and the theoretical data (dotted line 3) are obtained with using the standard Schreiber-type algorithm. In whole an analysis shows that almost all the peaks on the actual curve repeated on the prognostic difference between the forecast and the actual data in the event of high concentrations of the ingredients can be quite large. The prediction line 2 looks more exact in comparison with actual data. In Table 3 we list the quantitative indictors of the forecast effectiveness. It can be seen that with decreasing predictability the quality of the forecast improves, that is, the results of the method are very similar to those that can be obtained by other methods. In order to check how well the model is built, it reflects the entire time series, a forecast was also made for 900 randomly selected terms. The success of the forecast turned out to be slightly improved (Table 3 ). 
Table 3.

Correlation coefficient (r) between actual and predictive series and rms prediction error $(\sigma)$ for different predictions timeliness $\left(\mathrm{NO}_{2} ;\right.$ two sites) for the last 100 raw points and 900 randomly chosen raw points

\begin{tabular}{|l|c|c|l|l|l|l|l|l|l|}
\hline & $6 \mathrm{~h}$ & $12 \mathrm{~h}$ & $18 \mathrm{~h}$ & $24 \mathrm{~h}$ & & $6 \mathrm{~h}$ & $12 \mathrm{~h}$ & $18 \mathrm{~h}$ & $24 \mathrm{~h}$ \\
\hline \multicolumn{3}{|c|}{ Site 1; Last 100 points of a raw } & \multicolumn{5}{c|}{ Site 1; 900 random points } \\
\hline$R$ & 0.98 & 0.98 & 0.97 & 0.96 & $r$ & 0.99 & 0.99 & 0.98 & 0.98 \\
\hline$\Sigma$ & 3.825 & 4.019 & 5.233 & 6.025 & $\sigma$ & 3.711 & 3.891 & 4.338 & 5.011 \\
\hline \multicolumn{3}{|c|}{ Site 2; Last 100 points of a raw } & \multicolumn{5}{c|}{ Site 2; 900 random points } \\
\hline$R$ & 0.99 & 0.99 & 0.98 & 0.97 & $r$ & 0.99 & 0.99 & 0.99 & 0.98 \\
\hline$\Sigma$ & 3.611 & 3.938 & 4.839 & 5.636 & $\sigma$ & 3.567 & 3.899 & 4.287 & 4.978 \\
\hline
\end{tabular}

To conclude, we have presented results of advances studying the temporal dynamics (time series) of the atmospheric pollutants (dioxide of nitrogen) concentration in atmosphere of the industrial ccities using earlier developed chaos-geometric approach and new prediction models. To reconstruct the corresponding attractor, the time delay and embedding dimension are determined. The LE spectrum, KaplanYorke dimension, KE etc are calculated. It is presented a new effective prediction model for description of the temporal dynamics of the air pollutants concentration.

\section{References:}

1. Gubanova E., Glushkov A., Khetselius O., Bunyakova Yu., Buyadzhi V., Pavlenko $E$., New methods in analysis and project management of environmental activity: Electronic and radioactive waste. - Kharkiv: FOP.-2017.

2. Khetselius O.Yu., Florko T.A., Svinarenko A.A., Tkach T.B., Radiative and collisional spectroscopy of hyperfine lines of the Li-like heavy ions and $\mathrm{Tl}$ atom in an atmosphere of inert gas // Phys.Scripta. - 2013. - Vol.T153-P.014037.

3. Glushkov A.V., Serbov N.G., Bunyakova Yu.Ya., Prepelitsa G.P., Svinarenko A.A. Sensing the kinetical features of energy exchange in mixture $\mathrm{CO}_{2}-\mathrm{N}_{2}-\mathrm{H}_{2} \mathrm{O}$ of atmospheric gases under interacting with laser radiation//Sensor Electr. and Microsyst. Techn. 2006. - № 4. - P.20-22.

4. Abarbanel H., Brown R., Sidorowich J., Tsimring L. The analysis of observed chaotic data in physical systems// Rev. Mod. Phys. - 1993. - Vol.65. - P.13311392.

5. Kennel M., Brown R., Abarbanel H. Determining embedding dimension for phasespace reconstruction using a geometrical construction // Phys.Rev.A. - 1992. Vol. 45. - P.3403-3411.

6. Packard N.H., Crutchfield J.P., Farmer J.D., Shaw R.S., Geometry from a time series// Phys. Rev. Lett. - 1980. - Vol. 45. - P. 712-716.

7. Schreiber T. Interdisciplinary application of nonlinear time series methods // Phys. Rep. - 1999. - Vol.308. - P. 1-64.

8. Glushkov A., Khetselius O., Bunyakova Yu., Prepelitsa G., Solyanikova E., Serga $E$. Non-linear prediction method in short-range forecast of atmospheric pollutants: 
low-dimensional chaos. In: Dynamical Systems - Theory and Applications. Lodz Univ. 2011, LIF111.

9. Glushkov A., Khetselius O., Kuzakon V., Prepelitsa G., Solyanikova E., Svinarenko A. Modeling of interaction of the non-linear vibrational systems on the basis of temporal series analyses (application to semiconductor quantum generators)// Dynamical Systems - Theory and Applications, Lodz Univ. 2011, BIF110.

10.Glushkov A., Khetselius O., Svinarenko A, Serbov N. The sea and ocean 3D acoustic waveguide: rays dynamics and chaos phenomena // J. Acoust. Soc. Amer. 2008. Vol.123(5). - P.3625.

11. Khetselius $O . Y u$., Forecasting evolutionary dynamics of chaotic systems using advanced non-linear prediction method // Dynamical Systems - Theory and Applications, Eds. J. Awrejcewicz et a.-2013. - Vol.1. - P.145-152.

12.Glushkov A., Safranov T., Khetselius O., Ignatenko A., Buyadzhi V., Svinarenko A. Analysis and forecast of the environmental radioactivity dynamics based on methods of chaos theory: General conceptions // Environm. Problems. - 2016. - Vol.1, №2. - P.115-120.

13.Ignatenko A., Buyadzhi A., Buyadzhi V., Kuznetsova A., Mashkantsev A., Ternovsky E. Nonlinear chaotic dynamics of quantum systems: molecules in an electromagnetic field // Adv. Quant. Chem. - 2019. - Vol.78. - P.149-170.

14.Serbov N., Svinarenko A. Wavelet and multifractal analysis of oscillations in system of couled autogenerators in chaotic regime // Photoelectronics. - 2006. Vol.15. - P.27.

15.Serbov, N., Svinarenko, A. Wavelet and multifractal analysis of oscillations in a grid of couled autogenerators// Photoelectronics. - 2007. - Vol.16. - P.53-56

16.Prepelitsa, G., Buyadzhi, V., Ternovsky, V. Non-linear analysis of chaotic selfoscillations in backward-wave tube // Photoelectronics. - 2013. - Vol.22. - P.103107

\author{
Бунякова Ю.Я., Хецеліус О.Ю., Флорко Т.О., \\ Глушков О.В., Свинаренко А.А., Дубровська Ю.В.
}

\title{
Хаос-геометричний підхід до аналізу, моделювання і прогнозування динаміки забруднюючих речовин в атмосфері промислових регіонів
}

\footnotetext{
АНОТАЦІЯ

Узагальнений хаос-геометричний підхід застосований до аналізу, моделювання та прогнозування часової динаміки концентрацій забруднюючих речовин (NO2) в атмосфері промислових міст. Підхід включає в себе такі методи нелінійного аналізу та теорії хаосу, як мультифрактальний формалізм, метод корелячійного інтеграла, аналіз на основі показників Ляпунова, ентропії Колмогорова, спектральні і прогнозні моделі, в m.ч., вперше з нейронномурежевим блоком. Для аналізу виміряних часових періодів кониентрацій діоксиду азоту фазовий простір системи було реконструйовано методом затримок. 3 метою виконання удосконаленого аналізу використовуються метод взаємної інформації, алгоритм корелячійного інтеграла, алгоритм помилкових найближчих сусідів, аналіз на основі показників Ляпунова і метод сурогатних даних. Метод кореля-
} 
иійної розмірності дозволив виявити дивний аттрактор з відносно невисокою фрактальною розмірністю. Розраховані динамічні і топологічні інваріанти, в тому числі, розмірності: вкладення, кореляиійна, Каплана-Йорка, показники Ляпунова, ентропія Колмогорова та ін. Аналіз отриманих даних підтвердив наявність елементів детермінованого хаосу в флуктуачійної часовій динаміці концентрацій атмосферних забруднювачів. Розроблено нову ефективну модель прогнозування тимчасової еволючійної динаміки концентрації забруднювачів повітря в атмосфері промислового міста. Наведено чисельні дані для коефіцієєнта кореляиії між фактичним і прогностичним рядами.

Ключові слова: флуктуачійна динаміка атмосферних забруднювачів, хаосгеометричний підхід.

\author{
Бунякова Ю.Я., Хещелиус О.Ю., Флорко Т.А., \\ Глушков А.В., Свинаренко А.А., Дубровская Ю.В.
}

\title{
Хаос-геометрический подход к анализу, моделированию и прогнози- рованию динамики загрязняющих веществ в атмосфере промышлен- ных регионов
}

\begin{abstract}
АНОТАЦИЯ
Обобщённый хаос-геометрический подход применен к анализу, моделированию и прогнозированию временной динамики концентращий загрязняющих веществ $\left(\mathrm{NO}_{2}\right)$ в атмосфере промышленных городов. Подход включает в себя такие методы нелинейного анализа и теории хаоса, как мульти фрактальный подход, метод корреляциионного интеграла, анализ на основе показателей Ляпунова, энтропии Колмогорова, спектральные и прогнозные модели, в т.ч., впервые с нейронносетевым блоком. Для анализа измеренных временных периодов концентрачий диоксида азота фазовое пространство системы было реконструировано методом задержек. С иелью выполнения усовершенствованного анализа используются метод взаимной информации, алгоритм корреляциинного интеграла, алгоритм ложных ближайших соседей, анализ на основе показателей Ляпунова и метод суррогатных данных. Метод корреляционной размерности позволил выявить странный аттрактор с относительно невысокой фрактальной размерностью. Рассчитаны динамические и топологические инварианты, в том числе, размерности: вложения, корреляиионная, Каплана-Йорка, показатели Ляпунова, энтропия Колмогорова и др. Анализ полученных данных показал наличие элементов детерминированного хаоса в флуктуационной временной динамике концентраций атмосферных загрязнителей. Разработана новая эффективная модель прогнозирования временной эволючионной динамики кониентращии загрязнителей воздуха в атмосфере промышленного города. Приведены численные данные для коэффиџиента корреляции между фактическим и прогностическим рядами.
\end{abstract}

Ключевые слова: флуктуационная динамика атмосферных загрязнителей, хаосгеометрический подход. 